Мельник Н. Г.

кандидат філологічних наук, доцент, завідувач кафедри української та світової літератур Криворізького педагогічного інституту ДВНЗ «КНУ»

\title{
УКРАЇНСЬКА СОЦІАЛЬО-ПОБУТОВА КАЗКА: ДИНАМІКА ТРАДИЦІї ФОЛЬКЛОРНОЇ СВІДОМОСТІ
}

У статті йдеться про функціонування традиційних рис фольклорної свідомості, щьо репрезентовані в українській народній соціально-побутовій казці. Особливу увагу звернено на трансформацію семантики сочіально-побутових кодів.

Ключові слова: сочіально-побутова казка, фольклорна свідомість, код.

В статье идет речь о функционировании традиционных черт фольклорного сознания, которые представлены в украинской соииально-бытовой сказке. Особенное внимание обращено на трансформацию семантики сочииально-бытовых кодов.

Ключевые слова: сочиально-бытовая сказка, фольклорное сознание, код.

The article deals with functional traditional features of consciousness in folklore, represented by the Ukrainian folk tales of everyday life. Particular attention was paid to semantic transformation of social and living codes.

Keywords: tales of everyday life, folklore consciousness, code.

Дослідження динаміки фольклорної свідомості - один із актуальних напрямків сучасної фольклористики, стан якої науковці визначають як особливий «період інтенсифікації, якому властиві поглиблене вивчення давніх $i$ нових пластів фольклору, видожанрових та оказіонально-функиіональних змістоформ, увага до об’єктивної історії наукової галузі»] [Український фольклор 2014: 5].

На думку I. Голованова під фольклорною свідомістю слід розуміти «<..> ідеальний об’єкт як сукупність (систему) уявлень, образів, ідей, які отримують свою репрезентащію в творах фольклору» [Голованов 2009: 44].

I. Кімакович трактує фольклорну свідомість «як сукупність моделей (чи модель) народного світозображення» [Кімакович 2014: 37].

Фольклорна свідомість, на нашу думку, реалізується в народному творі через його ідейний зміст, відображений крізь призму традиційних естетичних норм, національної системи цінностей, розуміння ідеалу як такого. Трансформації таких норм та цінностей, покликані до життя історичними, 
політичними, соціальними, психологічними чинниками логічно призводять до трансформацій фольклорної свідомості загалом.

Аналіз стану, функціонування, динаміки фольклорної свідомості $є$ необхідним із огляду на розуміння фольклору як «універсального засобу вираження ментальності, важливого чинника формування національної самосвідомості, формування духовного свіму особистості, ї̈ моральноестетичного розвитку, психологічної самодостатності $i$ комфорту» [Український фольклор 2014: 5].

Ми погоджуємося 3 твердженням I. Кімакович щодо важливості проблеми дослідження фольклорної свідомості, адже, на іï думку, «питання про естетичні принщипи побудови моделей фольклорного світу переростає у питання про історичну динаміку жанрової свідомості, про реконструкцію тих ї̈ ментальних конструктів та конструкцій, які в кінцевому результаті сформували раціональність та об'єктивність (у тих формах, щ̧о їх пропагує сьогодні наука)» [Кімакович 2014: 55].

Проблема традиції $є$ однією 3 найскладніших у фольклористичному науковому дискурсі. Традиція і новаторство, успадковане та набуте, стійке та змінне в фольклорі - теми, що й досі перебувають в активі досліджень сучасної науки про народну творчість.

Ми погоджуємося із визначенням поняття «традиція», сформульованому в праці Л. Яроцького «Традиції і формування світогляду», в якій автор зазначає: «... традищію слід розглядати як сталий запас уявлень, поглядів, ідей, способів організащиї $i$ поведінки народу, нащчї, соцуіальних етнічних груп людей, які проявляються у всіх сферах суспільного буття i суспільної свідомості, передаються з покоління в покоління $i$ закріплюються силою громадської думки» [Яроцький 2003: 11]. Цінним, на нашу думку, також є спостереження науковця про закономірну взаємопов'язаність традицій із розвитком суспільства. Саме тому, як вважає Л. Яроцький, традицію обов'язково слід розглядати крізь призму суспільних відносин [Яроцький 2003: 11-13]. 
I. Головаха-Хікс у праці «Оповідач та динаміка усної прозової традиції» вказує на ще один важливий чинник формування фольклорної свідомості - це особистість наратора. Авторка дослідження справедливо зазначає, що поряд із наявністю в оповідача творчої індивідуальності, важливою $є$ його залежність від норм традиції та соціально-історичних попитів часу.

На думку дослідниці, «члени фольклорного осередку складають своєрідну «малу групу», в якій формуєтья специффічна символічна мова, зрозуміла лише тим, хто в иьвому осередку виховувався, або жив тривалий час. Члени осередку повинні знати та вміти розтлумачити не лише текст, але й той контекст, щзо його супроводжує» [Головаха-Хікс 1997: 148-150].

Отже, рівень фольклорної свідомості народного твору визначають: стан розвитку суспільства та індивідуальні особливості виконавця-оповідача, який перебуває під впливом традиційно-орієнтованого середовища.

Соціально-побутові казки - один із найцікавіших пластів українського фольклору з огляду на концентрацію в них традиційних народних поглядів на різні соціальні явища та психологічно-поведінкові особливості представників суспільних верств.

До вивчення художньої природи соціально-побутової казки зверталися Є. Мелетинський, В. Пропп, Ю. Юдін, М. Вавілова, Л. Барабанова, I. Березовський, I. Хланта, Л. Дунаєвська, В. Давидюк, О. Бріцина та інші дослідники.

На думку О. Бріциної, «соиіально-побутова казка відрізняється від інших жанрових різновидів специфікою відображення дійсності, характером зображення героїв, особливостями художнього часу $i$ простору», $a$ ï̈ тематика «значно більи різноманітна, ніж тематика казок про тварин $i$ фантастичних» [Бріцина 1989: 7-8].

Характеризуючи цей пласт казкового епосу В. Давидюк зазначає: «С казки, у яких справжньої казковості - як кіт наплакав. Більшість їх сюжетів не виходить за межі реального. Так можна охарактеризувати значну частину побутових казок. Часто їх ще називають суспільно-побутовими, хоч з 
огляду на персонажний склад для них більше підійшла б назва соиіальнопобутових, адже їхні персонажі мають доволі чітке соиіальне маркування. Конфлікти ицих сюжетів також лежать у сочіальній площині» [Давидюк 2007: 40].

Л. Дунаєвська підкреслює, що конфлікт соціально-побутових творів виникає в сфері сімейних чи соціальних відносин між добротворцями та злотворцями, які у більш ранніх казках реалізуються в зооморфних образах Долі та Недолі, Щастя та Біди, Горя, Злиднів і т.д. Виходячи 3 характеру головного конфлікту, Л. Дунаєвська умовно поділяє твори на дидактичні, сімейно-антагоністичні, гумористичні та сатиричні. До дидактичних фольклористка відносить твори, в яких відображено уявлення народу про залежність життя людини від долі, щастя, злиднів; до сімейноантагоністичних - твори про старшого та молодшого братів, пасербицю та іï мачуху; до гумористичних - про ледачих людей, дурнів, про веселі походеньки солдат та циган; до сатиричних - антицарські, антипанські, антипопівські твори [Дунаєвська 1998: 138-139].

На нашу думку, найінформативнішою в сенсі відображення стану фольклорної свідомості, $є$ тематична група казок про Правду і Кривду та багатого і бідного братів («Правда і Неправда», «Убогий i багатий», «Про правду і кривду», «Правда і Кривда», «Про бідного і багатого брата» та інші). Саме вони відображають найтонші зміни суспільних настроїв, особливості світосприйняття представників різних соціальних прошарків та репрезентують народну систему цінностей.

Ми погоджуємося 3 думкою Ю. Юдіна щодо соціально-історичного кодування фольклорної свідомості, репрезентованій у соціально-побутовій казці: «Фольклорна свідомість - не чистий аркуш, на якому лише сучасність залишає свої позначки. Що стосується народної побутової казки, то можна сказати, що сучасний побут і сочіальні відносини переломлюються нею крізь призму народного історичного досвіду» [Юдін 1979: 2]. 
На нашу думку, твори вищеназваної тематичної групи $є$ результатом тривалого процесу осмислення народним генієм значення матеріального та духовного чинників життя людини. Від ідеї кровної помсти за образу члена роду фольклорна свідомість приходить до утвердження переваги духовних, морально-етичних цінностей над усіма іншими (навіть родинними).

Саме тому в цих казках дві антагоністичні (з соціального та моральноетичного поглядів) концепції людини реалізуються крізь призму світобачення представників однієї родини. Так Правда з відомої казки називає Неправду сестрицею, ділиться із нею останньою їжею, довіряє, як рідній [Семиліточка 1990: 246-249]. Неправда ж обдурює сестру, виколює їй очі, а потім залишає напризволяще. Так у творі «Правда і кривда» багатий брат калічить (виколює очі) бідного за мірку хліба. Мотив виколювання очей варіюється й в інших творах (відрубування рук, вбивство), що надає творам емоційності, експресивності, змушує співпереживати героям казки-жертвам несправедливості та формувати власне ставлення до кривди в усіх іiі виявах: «Як же чее ти, чоловіче, будеш на світі жити без очей? < .. > Плаче сердешна так, щзо ц̌ слова не промовить» [Українські народні казки 1996: 602].

Образна система названих творів характеризується чіткою визначеністю народного генія щодо соціальної приналежності героїв. Як правило, саме соціальне маркування персонажів казки передбачає наявність у них відповідних особистісних рис. Так Правда, бідний брат, бідний племінник - чесні, щедрі, добрі; Неправда, Кривда, брат-багач, багатий дядько - брехливі, жадібна, злі.

Народ у своїх позиціях досить категоричний: матеріальне багатство майже ніколи не супроводжує життя чесної, справедливої, порядної людини (як виняток, у казці іноді постають образи царя або пана, які, за сюжетом, справедливо вирішують суперечку між героями. Проте ці образи відіграють більше формальну роль, ніж змістову).

Правда і Кривда можуть поставати в творах як звичайними людьми, так i фантастичними істотами, носіями негативних рис, притаманних людині загалом. 
У творах спостерігається взаємоперехідність таких образів від людських до антропоморфних і навпаки. Так у казці «Правда і Кривда» мати називає синів відповідними іменами лише після спостереження за їхньою поведінкою: «Якось жила собі бідна вдовиия. Мала двох синів. Один хлопещь був дуже справедливий, другий - несправедливий, бо де тільки міг, всюди чинив кривду. Так мати синів і назвала: молодшого - Правдою, а старшого - Кривдою» [3 живого джерела 1990: 401]. Кінець цієї ж казки свідчить про те, що образи Правди і Кривди набирають символічного значення і вже не прив'язуються до реальної, обмеженої певними часовими рамками історії стосунків двох братів: «Так Кривда домандрував, а Правда живе й нині» [3 живого джерела 1990: 403].

О. Бріцина спостерегла, що казка становить певну художню систему, яка «своєрідно поєднує риси, набуті протягом більш ніж тисячолітньої історії $i$ відстояні у віках, з елементами відносно новими, поява яких зумовлена потребами і особливостями сучасного функиіонування» [Бріцина 1989: 7].

Усі казкові твори названої тематичної групи закінчуються перемогою правди над неправдою, встановленням справедливості:

1) «А багатир прожогом хотів утекти поміж ними, так його й схопили на списи, не дали йому й пирхнуть» [Українські народні казки 1996: 613];

2) «Кинулись шукати (нечисті - Н. М.) - та на дерево, аж там той багач...То вони його як схопили, так і розірвали...» [Українські народні казки 1996: 604].

3) «Узявши мотузок, пішов у ліс на те саме місие, де хотів віматись його небіж. Але изьому не так прилучилося - де не взялись чортяки, схопили його та й почепили на найвищій гілляиі» [Семиліточка 1990: 255].

Часто кінець казки має виховну спрямованість: утверджується думка про обов'язковість дотримання людиною приписів традиційної моралі, інакше іiі чекає покарання: 
1) «Прив'язали ворони на шию Кривді мотуз i підтягли вгору. Потім взяли таблищю й написали: «Хто лихою дорогою ходить, на такій і пропадає!» [3 живого джерела 1990: 403].

2) «Цар, як скінчила Правда розказувати, звелів узяти Неправду, прив'язати ї̈ коневі до хвоста й пустити його на волю, щоб розніс ї̈.

3) От так, - сказала Правда, - пройшла вона світ - назад не вернулась!» [Семиліточка 1990: 249].

На думку О. Бріциної, «...нереальні з точки зору здорового глузду казкові ситуації вказують на реальні процеси і глибинні суперечності, допомагають критично осмислити явища соиіальної дійсності» [Бріцина 1989: 9].

Отже, аналіз ідейного змісту, системи образів української народної дидактичної соціально-побутової казки дозволяє зробити висновок про сформованість у межах фольклорної свідомості пріоритетності духовного в житті людини над фізичним, матеріальним.

\section{БІБЛІОГРАФІЯ}

Бріцина 1989 - Бріцина О. Ю. Українська народна соціально-побутова казка / Олександра Юріївна Бріцина. - К: Наукова думка, 1989. - 152 с.

Голованов 2009 - Голованов И. А. Фольклорное сознание как особый тип художественного освоения действительности / И. А. Голованов // Вестник Челябинского государственного университета, 2009. - № 22(160). Филология. Искусствоведение. - Вып. 33. - С. 43-47.

Головаха-Хікс 1997 - Головаха-Хікс І. Є. Оповідач та динаміка усної прозової традиції: дис. ... канд. філол. наук: 10.01.07 / Інна Свгенівна ГоловахаХікс. - К., 1997. - 175 л.

Давидюк 2007 - Давидюк В. Доісторичне поле української казки // Концепції і рецепції / Віктор Феодосійович Давидюк. - Луцьк: Твердиня, 2007. $-288 \mathrm{c}$.

Дмитренко 2004 - Дмитренко М. К. Казки на все життя/ Микола Костьович Дмитренко // Українські народні казки [Упоряд., передмова Миколи Дмитренка]. - К. : Видавець Микола Дмитренко, 2004. - 384 с. 
Дунаєвська 1987 - Дунаєвська Л. Ф. Українська народна казка / Лідія Францівна Дунаєвська. - К. : Вища школа, 1987.

Дунаєвська 1998 - Дунаєвська Л. Ф. Українська народна проза (легенда, казка). Еволюція епічних традицій / Лідія Францівна Дунаєвська / Дисертація д-ра філол. наук: 10.01.07 / Київський університет ім. Тараса Шевченка. - К., 1998. - 447 c.

3 живого джерела 1990 - 3 живого джерела: Українські народні казки в записах, переказах та публікаціях українських письменників [Упоряд., літ. оброб., вступ. ст. та приміт. Л. Ф. Дунаєвської].- К. : Рад. шк., 1990. - 512 с.

Калинова сопілка 1998 - Калинова сопілка [Антологія української народної прозової творчості]. - 1998. - С. 34-246.

Кімакович 2014 - Кімакович І. Фольклорна свідомість в теорії естетики / I. Кімакович // Український фольклор: методологія дослідження, динаміка функціонування: Колективна монографія [За редакцією М. К. Дмитренка]. - К. : ПАЛИВОДА А. В., 2014. - С. 21-39.

Кімакович 2014 - Кімакович I. Фольклорна свідомість: естетичні моделі фольклорної дійсності // Український фольклор: методологія дослідження, динаміка функціонування: Колективна монографія [За редакцією М. К. Дмитренка]. - К. : ПАЛИВОДА А. В., 2014. - С. 58-71.

Семиліточка 1990 - Семиліточка: Українські народні казки у записах та публікаціях письменників XIX-поч.ХХст. [Упоряд., передм. $\mathrm{i}$ приміт. Л. Ф. Дунаєвської] - К. : Веселка, 1990.- 319 с.

Українські народні казки 1996 - Українські народні казки. - К. : Ірпінь, 1996. $-656 \mathrm{c}$.

Український фольклор 2014 - Український фольклор: методологія дослідження, динаміка функціонування: Колективна монографія [За редакцією М. К. Дмитренка]. - К. : ПАЛИВОДА А. В., 2014.- 252 с.

Юдин 1979 - Юдин Ю. И. Русская народная бытовая сказка: автореф. дис... на здобуття наук. ступеня докт. филол.наук / Ю. И. Юдин - Л., 1979. $32 \mathrm{c}$. 
Яроцький 200 - Яроцький Л. В. Традиції і формування світогляду / Леонід Васильович Яроцький. - Житомир : Полісся, 2003. - 234 с. 